\title{
INTRODUÇÃO À CONSTITUIÇÃO MATERIAL
}

\section{INTRODUCTION TO THE MATERIAL CONSTITUTION ${ }^{1}$}

\author{
Marco Goldoni ${ }^{2}$ \\ Michael Wilkinson ${ }^{3}$ \\ Tradução: Jairo Néia Lima
}

\begin{abstract}
Como citar este artigo / How to cite this article (informe a data atual de acesso / inform the current date of access):
GOLDONI, Marco; WILKINSON, Michael. Introdução à constituição material. Tradução Jairo Néia Lima. Revista da Faculdade de Direito UFPR, Curitiba, PR, Brasil, v. 63, n. 3, p. 265-299, set./dez. 2018. ISSN 2236-7284. Disponível em: $\quad<$ https://revistas.ufpr.br/direito/article/view/60907>. Acesso em: 22 dez. 2018.2 DOI: http://dx.doi.org/10.5380/rfdufpr.v63i3.60907.
\end{abstract}

\section{RESUMO}

Qual é o contexto material da ordem constitucional? Este artigo busca oferecer uma resposta a essa pergunta, por meio do esboço de uma teoria da constituição material. Diferentemente de outras abordagens, tais como o constitucionalismo sociológico, o constitucionalismo marxista e a teoria política do direito, este artigo descreve os elementos básicos da constituição material, especificando seus quatro fatores de ordenação. São eles: a) unidade política, b) conjunto de instituições; c) rede de relações sociais, e d) conjunto de objetivos políticos fundamentais. Esses fatores fornecem a substância material e a dinâmica interna do processo de ordenação constitucional. Eles não são externos à constituição, mas correspondem a característica do conhecimento jurídico, situando-se em uma relação e tensão internas com a constituição formal. Em razão do fato de que esses fatores de ordenação são múltiplos e conflitantes entre si, não existe um único fator determinante do desenvolvimento constitucional; nem sequer essa ordem é garantida. O conflito que caracteriza a condição humana moderna pode, mas não precisa, ser internalizado pelo processo de ordenação constitucional. Em suma, a teoria da constituição material oferece uma descrição dos elementos básicos desse processo, bem como de sua dinâmica interna.

\section{PALAVRAS-CHAVE}

Teoria da Constituição. Costantino Mortati. Ordenação constitucional.

\begin{abstract}
What is the material context of constitutional order? The purpose of this paper is to offer an answer to that question by sketching a theory of the material constitution. Distinguishing it from related approaches, in particular sociological constitutionalism, Marxist constitutionalism, and political jurisprudence, the paper outlines the basic elements of the material constitution, specifying its four ordering factors. These are a) political unity, b) a set of institutions, c) a network of social relations, and d) a set of fundamental political objectives. These factors provide the material substance and internal dynamic of the process of constitutional ordering. They are not external to the constitution

\footnotetext{
${ }^{1}$ Artigo original em inglês, traduzido mediante autorização dos autores [N. do T.]. Artigo original disponível em: $<$ https://goo.gl/CsN2Ue>.

${ }^{2}$ University of Glasgow - School of Law. E-mail: Marco.Goldoni@glasgow.ac.uk

${ }^{3}$ London School of Economics - Department of Law. E-mail: M.Wilkinson@lse.ac.uk

${ }^{4}$ Doutor em Direito do Estado pela Faculdade de Direito da Universidade de São Paulo (FD/USP). Pesquisador Visitante na Universidade de Glasgow (Escócia).E-mail: jaironlima@yahoo.com.br
} 
but are a feature of juristic knowledge, standing in internal relation and tension with the formal constitution. Because these ordering factors are multiple, and in conflict with one another, there is no single determining factor of constitutional development. Neither is order as such guaranteed. The conflict that characterizes the modern human condition might but need not be internalised by the process of constitutional ordering. The theory of the material constitution offers an account of the basic elements of this process as well as its internal dynamic.

\section{KEYWORDS}

Constitutional Theory. Costantino Mortati. Constitutional ordering.

\section{INTRODUÇÃO}

O estudo normativo da constituição na Europa enfrenta um certo esgotamento. Em grande parte, devido à influência da ciência política e da teoria constitucional norte-americana, a pesquisa constitucional tornou-se estritamente focada na proteção das normas constitucionais e na aplicação judicial dos direitos individuais. O papel especial desempenhado pelas cortes constitucionais e, em particular, pelo Tribunal Constitucional alemão indicou uma abordagem cada vez mais “jurídica” do constitucionalismo ${ }^{5}$. Se a constituição fosse o que a corte diz que ela é, a tarefa do constitucionalista seria fornecer orientação normativa e hermenêutica para ajudar os juízes em seus processos de raciocínio jurídico. Isso coincide com a judicialização mais ampla das políticas constitucionais, apropriadamente caracterizada por Ran Hirschl como “juristocracia”, a qual é plenamente aceita pelos constitucionalistas jurídicos como o melhor arranjo institucional para manter a constituição e proteger os direitos individuais contra os abusos políticos ${ }^{6}$.

Não é surpresa que, no início do milênio, uma nova onda de constitucionalismo político tenha entrado em cena. Após uma primeira onda liderada por J. A. G. Griffith, que capturou a natureza política da constituição britânica bem como a sua morte iminente em sua famosa conferência sobre “A Constituição Política” em 19797 , a segunda onda transcendeu o contexto britânico ${ }^{8}$. Ela teve, ao menos, um efeito benéfico: os constitucionalistas foram impelidos a questionar as metodologias interpretativas criadas com foco nas cortes, o "ramo menos perigoso" no aforismo de Alexander Bickel. Eles foram forçados a levar mais a sério as limitações do poder judicial e convidados a voltar

\footnotetext{
${ }^{5}$ Cf. C. Möllers, 'We are (afraid of) the people', in M. Loughlin and N. Walker (eds), The Paradox of Constitutionalism: Constitutional Power and Constitutional Form (Oxford University Press, 2007) 87-107.

${ }^{6}$ R. Hirschl, Towards Juristocracy: The Origins and Consequences of the New Constitutionalism (Harvard University Press, 2004).

7 J. A. G. Griffith, ‘The Political Constitution’ (1979) Modern Law Review 1-21.

${ }^{8}$ Para uma análise dessas ondas: M. Goldoni and C. McCorkindale, 'Political Constitutionalism', in M. Sellers (ed), Encyclopedia of the Philosophy of Law and Social Philosophy (Springer, 2017) (no prelo).
} 
seus estudos para a autoridade parlamentar e para o exercício crescente e ilimitado do Poder Executivo ${ }^{9}$.

Todavia, com algumas exceções, essa virada permaneceu normativa, redutora, formal, vinculada a premissas individualistas e incapaz de oferecer explicações conceituais sobre o constitucionalismo ou o desenvolvimento constitucional ${ }^{10}$. Ela se restringiu às reivindicações da superioridade dos parlamentos sobre as cortes para responsabilizar o presidente e determinar as disputas de direitos, posicionando-se normativamente contra a crença do constitucionalismo jurídico no raciocínio judicial. Questões mais amplas do poder constituinte e da teoria do estado, todavia, foram amplamente evitadas.

Em suma, o constitucionalismo político era insuficientemente político e pouco sintonizado com o conceito de político ${ }^{11}$. Essa vertente permaneceu muda diante das renovadas crises constitucionais e político-econômicas, bem como impermeável à natureza cada vez mais rica das relações sociais subjacentes ao constitucionalismo, as quais fomentavam a instabilidade constitucional. Os constitucionalistas políticos e jurídicos negligenciaram tanto as relações materiais que condicionam o surgimento e o desenvolvimento de uma ordem constitucional como as mudanças nessas relações que levam à suspensão ou modificação de normas constitucionais formais. A compreensão desses fenômenos demanda atenção ao contexto material subjacente, às condições políticas e sociais básicas de possibilidade do constitucionalismo e à dinâmica da mudança constitucional. A teoria constitucional mainstream (seja o constitucionalismo político ou jurídico) tem pouco a dizer sobre os desafios mais importantes para o ordenamento constitucional atual: a crise existencial da zona do euro; a fratura da unidade política do Estado ou o retorno de movimentos políticos e sociais antissistêmicos.

A constituição material é claramente complexa. Para reduzir a complexidade e obter uma vantagem analítica neste terreno, identificamos quatro “camadas”-chave (não necessariamente exclusivas) da constituição, às quais a constituição formal se relaciona: unidade política, cuja forma dominante permanece no moderno Estado-nação; um conjunto de instituições, incluindo, mas não limitado a eles, os ramos oficiais do governo, tais como tribunais, parlamentos e executivos; uma rede

\footnotetext{
${ }^{9}$ E. A. Posner and A. Vermuele, The Executive Unbound (Oxford University Press, 2011). Cf. T. Poole, Reason of State (Cambridge University Press, 2015).

10 Cf. K. Ewing, 'The Resilience of the Political Constitution' (2013) 14 German Law Journal 2111; O. Beaud, 'Reframing a debate amongst Americans: Contextualising a Moral Philosophy of Law' (2009) International Journal of Constitutional Law 53-68.

${ }^{11}$ Cf. P. Minkinnen, 'Political Constitutionalism vs. Political Constitutional Theory: Law, Power and Politics' (2015) 11 International Journal of Constitutional Law 585-610.
} 
de relações sociais, de interesses de classe e movimentos sociais, e um conjunto de objetivos políticos fundamentais (ou teloi). Elas compõem os fatores de ordenação da constituição.

Após uma análise metodológica preliminar, contrastando essa abordagem com outras semelhantes (parte 1), examinamos cada um desses quatro fatores de ordenação (parte 2). Finalmente, concluímos (parte 3) argumentando que a constituição material não é um campo de conhecimento extrajurídico nem um transmissor direto de normas legais. Trata-se de um campo de conhecimento jurídico, cujo conteúdo é dinâmico e continuamente contestado em sua relação interna com a constituição formal.

\section{CONTRASTANDO A CONSTITUIÇÃO MATERIAL}

As condições de formação e durabilidade constitucional incluem economia e cultura política, relações sociais, religião, fatores geopolíticos, relações internacionais e formas de dominação imperiais. Não se quer dizer, no entanto, que o desenvolvimento das constituições modernas seja moldado apenas por esses fatores externos, como se fossem meros incômodos para uma ordem já estabelecida, mas que eles se combinam para constituir a própria ordem e condicionar o desenvolvimento constitucional por meio de processos de reordenamento (e de desordem).

Essas características podem estar integradas na investigação constitucional quando se colocam suas relações com a constituição no centro da análise. Para os constitucionalistas essa abordagem significa tomar como questão de conhecimento jurídico conceitos geopolíticos, políticos e sociais, os quais foram anteriormente delegados - ou relegados - para outras disciplinas, como a sociologia, as relações internacionais e a teoria política.

Começamos essa abordagem da constituição material relacionando-a à constituição formal - os textos constitucionais e as convenções não escritas, conforme interpretação dos órgãos oficiais. Se a constituição formal é a soma de todas as normas e princípios constitucionais que orientam a regulação das interações políticas e sociais (constituindo a “lei das leis”), ela se relaciona com a constituição material, mas não apenas como uma relação entre forma e conteúdo. Uma análise da função e do conteúdo das normas constitucionais é, naturalmente, um primeiro e importante passo em qualquer questionamento constitucional. As constituições não só estabelecem e regulamentam o processo formal de elaboração de leis, elas invariavelmente protegem certos interesses materiais, da liberdade de expressão ao equilíbrio orçamentário. Isso já nos diz algo sobre o conteúdo da constituição, pelo menos como um conjunto de metas aspiracionais ou objetivos políticos e sociais. 
Entretanto, a constituição material não é meramente o “conteúdo” da constituição formal ou a totalidade das normas constitucionais formais (mesmo quando abrange normas informais e princípios); nem compete com, substitui ou se mantém em relação antagônica à validade da constituição formal. O objetivo da investigação constitucional material, em última instância, tem caráter explicativo e não normativo (ou ideológico). Ela fornece uma compreensão da dinâmica de ordenação (e desordenação) da mudança constitucional. O que deve seguir como uma matéria de interpretação constitucional corresponde a uma questão de moralidade política e julgamento prudente.

Este ponto deve ser apresentado claramente: a constituição material não determina a validade legal por si só, nem determina o resultado da ação política ou da adjudicação judicial. Isso pode ser o caso especialmente dos episódios de crise política, quando as normas jurídicas positivas são ignoradas, pressionadas por forças materiais claramente identificáveis ou cobertas por restrições materiais. No entanto, períodos críticos, em que as forças materiais se direcionam para lados antagônicos e abrem caminhos alternativos para mudanças constitucionais também revelam a indeterminação da constituição material.

Em vez disso, a constituição formal é uma característica, uma instância, da constituição material ${ }^{12}$, parte da ordem constitucional mais ampla. Sem uma constituição material correspondente e sem tração política e social, uma constituição formal continua a ser uma "letra morta”, uma lista de auspícios ilusórios ou mesmo uma “farsa”. Nesse caso, a forma e a função podem até questionar o próprio discurso da constituição e do constitucionalismo. Entretanto, para adotar a linguagem do jurista alemão-judeu do século XIX, Ferdinand Lassalle, a distância entre a "constituição jurídica [ou formal]” e uma "constituição real” (as relações reais de poder em um país) deve ser entendida como uma questão de direito e teoria constitucional ${ }^{13}$. É importante notar também que essa distância existe tanto nos regimes liberais democráticos quanto nos regimes não liberais e não democráticos. Pode-se dizer que todas as constituições são relativamente falsas, dada a distância entre suas aspirações formais e sua realidade vivida.

A “distância” entre a forma constitucional e a constituição material é, obviamente, uma questão de grau e não depende de muita precisão analítica. Entretanto, a metáfora da distância é de fato enganosa na medida em que sugere uma dicotomia, enquanto a relação entre a “constituição

\footnotetext{
${ }^{12}$ C. Mortati, La costituzione in senso materiale (Giuffré, 1940) 138. Comentários a Mortari em inglês: M. La Torre, 'The German Impact on Fascist Public Law: Costantino Mortati’s Material Constitution' and G. Della Cananea, 'Mortati and the Science of Public Law’, in C. Joerges, N. Ghaleigh (eds), Darker Legacies of Law in Europe (Hart Publishing, 2003) 305-20 e 321-336.

${ }^{13}$ F. Lassalle, 'Uber Verfassungswesen' in 2 Gesammalte Reden Und Schriften 38 (E. Bernstein, ed).
} 
formal” e a “constituição material” é mais bem caracterizada como uma relação interna. Mesmo uma constituição essencialmente falsa pode ter certos efeitos civilizatórios sobre o comportamento oficial e até um regime autoritário pode buscar por dispositivos constitucionais para garantir sua legitimidade ou eficácia na prática ${ }^{14}$.

Logo, falar de constituição material não é meramente insistir, como um positivista jurídico como Hans Kelsen, que a eficácia da lei, embora não seja o mesmo que sua validade, é uma condição de validade ${ }^{15}$. Isso, claro, é um truísmo. A autoridade de jure depende da (e é condicionada pela) autoridade de facto, como positivistas e jusnaturalistas admitem. No entanto, tanto a tradição positivista como a jusnaturalista mantêm uma metodologia de separação entre fato e norma, a qual é hostil à compreensão da constituição na prática e ao rastreamento do desenvolvimento constitucional na inter-relação entre fato e norma. Quais são as condições de eficácia e como a lei se relaciona com elas? Para essa questão o positivista não oferece respostas. O positivista (assim como o jusnaturalista) simplesmente assume a eficácia ou pressupõe a existência de uma "tradição constitucional permanente”. Ocorre que, em uma época em que tais tradições parecem cada vez mais precárias e a eficácia da própria lei está em dúvida, a questão deve ser posta novamente.

A rejeição do formalismo constitucional não é novidade. Por essa razão, é importante distinguir nossa abordagem de três outras da teoria constitucional, quais sejam: o constitucionalismo sociológico, o constitucionalismo marxista e a teoria política do direito.

O constitucionalismo sociológico, construído sobre a sociologia do direito, o pluralismo jurídico e a teoria dos sistemas desenvolveu variações no tema materialista. À medida que a autoridade institucional do Estado se fragmentou e a ordem política se tornou cada vez mais complexa e difusa, a identidade formal do direito e do Estado (constituição e Estado) torna-se problemática, se não insustentável. Um movimento recente e crescente na sociologia das constituições, desenvolvido a partir dos trabalhos de Niklas Luhmann, Gunther Teubner, Chris Thornhill e Marcelo Neves, baseiase nessa visão ${ }^{16}$. Seu ponto de partida lembra uma análise constitucional material: a existência de uma relação interna entre sociedade e constituição. Vale a pena nesse momento fazer uma pausa para distinguir a sociologia das constituições da abordagem discutida aqui.

A sociologia das constituições baseia-se em um funcionalismo que rejeitamos. O estudo dos sistemas funcionais, subsistemas e processos de diferenciação funcional oferece uma reconstrução

\footnotetext{
${ }^{14}$ Cf. T. Ginsburg and A. Simpser (eds) Constitutions in Authoritarian Regimes (Cambridge University Press, 2014).

${ }^{15}$ Cf. H. Kelsen, Introduction to the Problems of Legal Theory, translated by B.L. Paulson \& S.L. Paulson (Oxford: Clarendon Press, 1992).

${ }^{16}$ G. Teubner, Constitutional Fragments (Oxford University Press, 2012); C. Thornhill, A Sociology of Constitutions (Cambridge University Press, 2011): M. Neves, Transconstitutionalism (Hart, 2013).
} 
perspicaz de certas características do desenvolvimento social moderno, particularmente na esfera econômica. A constituição material, no entanto, não é funcional nem sistemática, mas, como argumentaremos a seguir, baseada em fatores de ordenação específicos.

Há três razões relacionadas com essa rejeição. Em primeiro lugar, a explicação sociológica das constituições em termos de funções, que, portanto, admite equivalentes funcionais, não pode explicar a razão pela qual a unidade política continua a ser fundamental para a análise constitucional ou por que certas funções são atribuídas a instituições políticas específicas. O constitucionalismo sociológico concebe a relação entre sociedade e constituições em termos de processos de inclusão e estabilidade (na perspectiva sociológica clássica). O desenvolvimento das constituições setoriais se desdobra seguindo a racionalidade funcional (e não governamental). Sua visão descentralizada perde a lógica abrangente e ordenadora do governo político.

Em segundo lugar, o constitucionalismo sociológico opera em termos de sistemas fechados e não de ordens, dando pouca atenção aos fatores de ordenação ou mesmo ao surgimento de desordem. A teoria dos sistemas confina o "político" aos sistemas políticos institucionalizados em um esforço para limitar a tendência expansionista e colonizadora da política ${ }^{17}$. Como consequência, resiste tanto à ideia de que a relação interna entre sociedade e constituições é substancializada por meio de atividades governamentais como à ideia de uma ordem constitucional organizada na busca de objetivos políticos básicos.

A terceira razão se relaciona com o fato de que a abordagem sociológica apoia uma racionalidade comunicativa que não deixa abertura constitucional suficiente para a subjetivação política, conflitos e movimentos sociais e forças antissistêmicas (cujo objetivo é mudar irregularmente a constituição ou em termos que afetem sua identidade substancial). Isso ocorre porque apenas as trocas comunicativas de acordo com o código relevante são registradas por um sistema ${ }^{18}$. A relação interna entre a constituição e a sociedade é concebida em termos totalmente irênicos, com exceção dos casos em que um sistema vai “atingir a base”"19. No entanto, a ordenação e a desordenação das forças constitucionais não podem ser explicadas em tais termos. O conflito é endêmico ao processo de ordenação constitucional, e não periférico a ele.

\footnotetext{
${ }^{17}$ Por uma exceção, cf. P. Blokker, 'Politics and the Political in Sociological Constitutionalism' in P. Blokker and C. Thornhill (eds) Constitutional Sociology (Cambridge University Press, no prelo).

${ }^{18}$ Cf. Teubner, ibid. Também: Habermas, Between Facts and Norms (MIT Press, 1992).

${ }^{19}$ Para uma crítica a esse argumento: E. Christodoulidis, 'On the Politics of Societal Constitutionalism' (2013) 20 Indiana Journal of Global Studies 629.
} 
A dimensão política, subjetiva e antagônica da constituição material sugere uma afinidade com a tradição marxista, a qual foi recentemente revitalizada na teoria constitucional por meio de Antonio Negri, e a visão aqui proposta compartilha dessas ideias ${ }^{20}$. A compreensão materialista de Negri da constituição permite focar no movimento em vez de nas origens e é capaz de explicar o desenvolvimento constitucional. Para Negri, a constituição material se refere à "formação e reformação contínuas da composição das forças sociais”21. Esse movimento é determinado mediante lutas de classes, as quais são consubstanciais com processos de subjetivação coletiva - a construção e a formação de sujeitos coletivos. A constituição material, portanto, evolui dentro de coordenadas espacialmente delimitadas (a fábrica, depois a própria sociedade) à medida que os sujeitos coletivos são formados. Este aspecto coletivo evita a redução da constituição material ao que pode ser chamado de “estrutura sem sujeitos”, ou relações de produção “naturais-sociais” (que incluem troca, direito, cultura, práticas ideológicas).

Da interpretação de Negri sobre a constituição material, não menos importante é sua advertência contra a visão de imposição à sociedade de uma ordem por uma elite já formada ${ }^{22}$. Negri oferece uma abertura insuficiente para atividades políticas destinadas a algo relativamente autônomo da luta social e, em versões posteriores de sua teoria, acaba por minar o papel produtivo do próprio conflito de classes. Não é coincidência que seu sujeito coletivo se torne a multidão (contrapartida de um Império igualmente nebuloso e unitário), e que a única coisa que falta para a reconstituição da constituição material é que essa multidão se torne consciente de seu status de trabalho vivo, isto é, como motor da reprodução social.

Por outro lado, na nossa visão, as lutas que animam a constituição material são conduzidas por uma pluralidade de sujeitos cujas posições são condicionadas, mas não determinadas por relações já estabelecidas. A subjetividade não decorre das relações sociais de produção e reprodução de uma maneira completamente direta e espontânea. Ela é mediada por organização, instituições e estratégias políticas. As forças econômicas e sociais não devem ser apresentadas como superdeterminantes da constituição material, porque, como ainda mostraremos, seu papel na formação da ordem constitucional deve ser entendido em termos relacionais e não apenas como um exercício de poder de cima para baixo (ou uma imagem de espelho de baixo para cima). As forças econômicas e sociais ordenam ativamente certos aspectos da constituição material, mas a composição dessas forças

\footnotetext{
${ }^{20}$ Cf. Insurgencies (Indiana University Press, 1999) ch 1. Negri compara sua abordagem com Teubner em: 'Law, Property and New Horizons' (2010) 21 Finnish Yearbook of International Law 1.

${ }^{21}$ A. Negri and M. Hardt, Empire (Cambridge: Harvard University Press, 2000) xiv.

${ }^{22}$ A. Negri, Labor of Dionysus (University of Minnesota Press, 1994) 63.
} 
também está constantemente sujeita a tensões e conflitos gerados por outros fatores políticos e institucionais da constituição.

Finalmente, também distinguimos nossa abordagem de uma tradição que recentemente foi revitalizada por Martin Loughlin, chamada de “teoria política do direito”23. Na visão de Loughlin, o conflito social se converte em uma disputa política gerenciável ao estabelecer uma unidade política geral de propósito e caráter. Isso é atingido por meio de dispositivos simbólicos e representativos característicos do Estado moderno, bem como pelo aparato coercivo do governo. O processo é mediado pelo direito público moderno, à medida que ele avança nas reivindicações dinâmicas do direito político (droit politique) ${ }^{24}$. A análise de Loughlin é uma correção crucial para a teoria do direito público normativista (tanto o constitucionalismo jurídico como o político) e, por meio do “trazendo o estado de volta”, é capaz de reconectar o direito público com tradições de teoria política que podem contribuir para uma abordagem materialista, de Hobbes e Rousseau, até Lassalle, Heller e Schmitt ${ }^{25}$.

A teoria política do direito, no entanto, apresenta reivindicações conflitantes sobre o bem comum em termos abstratos, naturalizando de forma hobbesiana a condição humana de antagonismo e reificando a relação entre governantes e governados. Essa teoria é, portanto, insuficientemente concreta, omitindo as circunstâncias do antagonismo e a materialidade da relação dominante. Essa relação não é condicionada apenas por circunstâncias materiais, mas também por ordenação constitucional, ela age e reconstitui relações materiais de formas particulares. Racionalizar a arte prudencial do governo exige levar em conta - o que falta na teoria política do direito - como o conflito material, as formas reais de dominação e a dinâmica do poder são traduzidos e, por sua vez, determinam a ordenação e o resultado das negociações políticas e do conteúdo do direito político. Em outras palavras, essa teoria não explica os fenômenos materiais - em particular a interação de subjetividades concretas de baixo, à medida que emergem mediante a luta política e de classes - que condicionam as reivindicações de direito político. Do ponto de vista materialista, esta omissão revela um resíduo de formalismo e até mesmo de ideologia, privilegiando uma forma contingente de “governar”, de relacionamento entre governantes e governados, negligenciando que essa relação não tem caráter apenas formal e político, mas também material e dinâmico.

Se a teoria política do direito oferece um relato convincente da "gramática” tradicional do direito público moderno e da autonomia do político, esse sistema depende exclusivamente da geração

\footnotetext{
${ }^{23}$ Cf. M. Loughlin, 'Political Jurisprudence’ (2016) 16 Jus Politicum 15.

24 Ibid.

${ }^{25}$ Cf. M. Loughlin, Foundations of Public Law (Oxford University Press, 2010).
} 
do poder político em e para si mesmo. A arte de governar requer uma autonomia relativa do político, mas na prática isso é gerado a partir de conflitos sociais e de processos de subjetivação política. Não basta transmitir a "lógica pura” por trás da estrutura de uma constituição ou de sua gramática jurisgenerativa (capaz de criar o direito), porque a constituição material é relacional e não mecânica na sua tradução de conflitos sociais em contestação política. Embora a teoria política do direito se centre na autonomia do político e no princípio da soberania como manifestação constitucional, o estudo da constituição material conceitua a arte de governar como uma atividade constitucional baseada em uma relação material entre governantes e governados. Isso, por sua vez, é contingente das relações sociais, incluindo a dinâmica das classes, e, quando o próprio Estado é trazido de volta, contingente das dinâmicas geopolíticas de poder e influência. Essas dinâmicas exigem explicação como parte da análise constitucional, pois são fundamentais para o processo de unificação política e formação constitucional ${ }^{26}$.

Na visão de Loughlin, o Estado como uma unidade política nunca pode ser totalmente capturado por categorias baseadas em regras, porque o conflito nunca pode ser resolvido na sua totalidade. Se essa afirmação for correta, o que torna possível qualquer ordem ou arranjo de governo relativamente estável em face da inescapável indecisão? Para Loughlin, a dinâmica é efetivamente administrada de forma prudencial de cima para baixo. A natureza material do elemento dinâmico é, portanto, implícita. Mas se “o estabelecimento de um domínio político é [...] uma conquista histórica”27, ele também é precário, particularmente porque, por meio da modernidade tardia, o acoplamento jurídico-político de que ele depende é posto sob uma crescente pressão das dinâmicas social, econômica e geopolítica. A ordem, em outras palavras, não pode ser deduzida. Isso não é mais evidente do que no período entre guerras na Europa, quando as relações de governo existentes, tanto dentro dos Estados como entre eles, tornaram-se instáveis até o ponto de rompimento. O projeto de integração europeia do final do século XX, que inaugura um processo de transformação do Estado, baseia-se em fatores materiais e geopolíticos que a teoria política do direito não consegue acomodar ${ }^{28}$. Com a relação de governo novamente em ponto de ruptura, é necessária uma análise constitucional material para dar sentido à dinâmica da mudança constitucional.

Em suma, se as tradições sociológicas e marxistas sofrem de um déficit político, a teoria política do direito sofre de um déficit material. Por um lado, as estruturas econômicas e as relações

\footnotetext{
${ }^{26}$ Esse ponto é explorado no item "unidade política”.

${ }^{27}$ Cf. Loughlin, 'Political Jurisprudence', 8 Jus Politicum.

${ }^{28}$ Cf. M. Wilkinson, 'The Reconstitution of Postwar Europe: Lineages of Authoritarian Liberalism', LSE Law Society and Economy Working Paper Series, 05-2016.
} 
sociais não são “uma acumulação de coisas inertes ou um curso transcendente da condição humana”29. Elas são o resultado de uma ação política subjetiva. De outro lado, a ação política não ocorre “em si e para si mesma”, pois é organizada e limitada pelas lutas materiais existentes. Étienne Balibar capta cuidadosamente a relação necessária entre o político e o material, destacando a materialidade da ação política moderna e observando que a verdade da política “deve ser buscada não na própria consciência de si mesma ou na sua atividade constituinte, mas na relação que ela mantém com as condições e objetos que formam seu "material" e a constitui como uma atividade material” ${ }^{30}$. Isso relembra a famosa visão de Marx, de que “os seres humanos fazem sua própria história, mas não conseguem fazê-la como querem; eles não a fazem sob circunstâncias autoescolhidas, mas sob circunstâncias já existentes, dadas e transmitidas do passado"31. As condições e relações materiais são, portanto, ambas constituídas (pela política) e constitutivas (da política). Essa dinâmica é intrínseca à ordem constitucional.

Uma vez que sempre existe uma relação interna entre a ordem constitucional e a sociedade, em contraste com a compreensão liberal clássica da constituição como um poder limitante imposto externamente à sociedade, a constituição é concebida como intrínseca à sociedade e como característica do poder político e social. Todavia, nesse contexto, o poder não é nem uma massa insurgente nem uma relação abstrata. A formação, a subsistência e a reprodução da sociedade sempre já implicam ordens constitucionais. Nesse sentido, o poder constitucional já é tanto poder constituído como poder constituinte, tal como reconstruído teoricamente por Hans Lindahl ${ }^{32}$. Mas como ele é ordenado? E por qual razão a ordem pode se transformar em desordem? Na próxima seção abordamos como organizar e conceituar o processo de ordenação constitucional, por meio do oferecimento de quatro blocos de análise interligados.

\section{OS QUATROS FATORES DE ORDENAÇÃO DA CONSTITUIÇÃO MATERIAL}

\section{A) UNIDADE POLÍTICA}

O primeiro fator de ordenação constitucional é a produção e reprodução da unidade política. Uma unidade política dá sentido a uma constituição; assim, podemos falar da Constituição alemã, da

\footnotetext{
${ }^{29}$ E. Balibar, Politics and the Other Scene (Verso, 2002) 11.

${ }^{30}$ Ibid, 10. Cf. também: J. Rancière, Disagreement (University of Minnesota Press, 1999) 16.

${ }^{31}$ De Marx: The Eighteenth Brumaire of Louis Napoleon available at www.marxists.org.

${ }^{32}$ Cf. H. Lindahl, 'Constituent Power and Reflexive Identity: Towards an Ontology of Collective Selfhood', in M. Loughlin, N. Walker (eds), The Paradox of Constitutionalism (Oxford University Press, 2007) 9-24.
} 
Constituição dos Estados Unidos ou da Constituição egípcia. A constituição existe como uma unidade política, não como um conjunto abstrato de normas. Mesmo aqui, no entanto, devemos notar imediatamente que as ambiguidades aparecem em relação ao contexto histórico. Estamos falando da Lei Básica da República Federal da Alemanha? Antes ou depois da reunificação? Antes ou depois da decisão OMT do Bundesverfassungsgerricht? ${ }^{33}$ Podemos, naturalmente, falar de uma ordem constitucional momentânea, mas isso não será muito revelador como questão de teoria constitucional. A ordem constitucional é sempre um processo de "vir a ser”.

Tradicionalmente, a ruptura em que a unidade política se constrói é imaterial: é a autonomia - e a primazia - do domínio político sobre o teológico que abre espaço para a ordem constitucional moderna. A transição do fundamento teológico da autoridade política para o racional, por mais incompleta que seja, foi capturada teoricamente desde os preceitos naturais de associação política em Hobbes, passa pela “nação” de Sieyès, até a narrativa de modernização de Weber. Essa transição foi recentemente abordada pela “tese da secularização” de Marcel Gauchet, a qual caracteriza a modernidade como um processo de desencanto religioso, marcado pela secularização dos fundamentos da autoridade política ${ }^{34}$. Nessas visões, o papel principal de avanço do processo de ordenação constitucional moderna é desempenhado pelo racional, imaginário e simbólico ${ }^{35}$. Desse modo, a unidade política se baseia em fundações seculares, na linguagem constitucional “nós, o povo” criamos nossa ordem política e jurídica.

Mas quais são as condições materiais desse processo de ordenação constitucional e a qual unidade política se relaciona? A formação da unidade política depende da compreensão do processo material de integração política (ou desintegração e reintegração, se for o caso) de uma coletividade. Em outras palavras, uma ordem constitucional representa um certo espaço político e se estende por um determinado período. Nicos Poulantzas caracteriza esses dois eixos como a matriz espaçotemporal da constituição ${ }^{36}$. Em nossa análise, a matriz pode ser considerada como as coordenadas que estabelecem as condições de possibilidade do constitucionalismo, tornando uma determinada ordem visível como ordem constitucional.

A análise constitucional material requer uma reconstrução do tipo de unidade política que emerge em épocas históricas e espaços geográficos específicos. Faz parte da análise constitucional material rastrear a forma particular que a unidade política toma, o que condiciona seu

\footnotetext{
${ }^{33}$ Caso de Transações Monetárias Definitivas (Outright Monetary Transactions Case) [N. do T.].

${ }^{34}$ M. Gauchet, The Disenchantment of the World: A Political History of Religion (Diane Publishing, 2001).

${ }^{35}$ Cf. M. Loughlin, ‘The Constitutional Imagination’ (2015) 78 Modern Law Review 1.

${ }^{36}$ Cf. N. Poulantzas, State, Power, Socialism (Verso, 2014).
} 
desenvolvimento e quais são as implicações constitucionais dessa forma específica. Se a unidade política é obtida por meio de um Estado-nação, de um Estado pluralista, de um Estado corporativo, de um Estado federal, de uma federação de nações, de uma dominação imperial, de uma confederação, de uma federação interestatal ou de uma união supranacional, trata-se de um momento significativo, porque reflete um caminho particular de desenvolvimento institucional e social e, portanto, de ordenação constitucional. Por outro lado, a constituição formal e a sua interpretação por parte dos órgãos oficiais podem ter um impacto significativo e mesmo decisivo no caminho tomado em direção à unidade política.

No entanto, apesar das variações e dos diferentes tipos de unidade política que emergem nesse processo de ordenação constitucional, o Estado-nação europeu moderno permanece (pelo menos na Europa) como a forma paradigmática de unidade política. Sua relação interna com a constituição material moderna merece, portanto, atenção particular, representando um “tipo ideal” de ordem constitucional.

O Estado-nação se consolida como uma unidade política mediante o estabelecimento de uma comunidade limitada, baseada em alguma combinação de território, idioma e identidade. Em uma perspectiva bastante influente, essa unidade política é construída como uma comunidade compartilhada de destino baseada no imaginário de pertencimento a uma nação ${ }^{37}$. O apego constitucional pode desempenhar um papel simbólico significativo nesse processo de formação de identidade coletiva, simbolizado na ideia de patriotismo constitucional ${ }^{38}$. A identidade, entretanto, também pode ser apresentada como um potencial pressuposto do constitucionalismo e, portanto, como um vetor ou até mesmo um obstáculo à mudança constitucional ${ }^{39}$.

O Estado-nação moderno também é consolidado como uma entidade politicamente soberana de duas maneiras, de acordo com o que Carl Schmitt chamou de Jus Publicum Europeaum ${ }^{40}$. Internamente, o Estado-nação europeu adquire o monopólio da força legítima no decorrer do "longo século 19” (da Revolução Francesa à Primeira Guerra Mundial). Externamente, ele é reconhecido como o único sujeito legítimo das relações internacionais, com o direito de decidir sobre questões de guerra e paz, sujeito de convenções relativas à guerra civilizada. O surgimento do Jus Publicum

\footnotetext{
${ }^{37}$ Cf. B. Anderson, Imagined Communities: Reflections on the Origin and Spread of Nationalism (Verso, 1983).

${ }^{38}$ Cf. J-W. Muller, 'A General Theory of Constitutional Patriotism' (2008) International Journal of Constitutional Law 72-95.

${ }^{39}$ Cf. e.g. D. Grimm, 'Does Europe Need a Constitution?’ (1995) European Law Journal 282.

${ }^{40}$ Cf. C. Schmitt, The Nomos of the Earth (Telos Press, 2006).
} 
Europeaum é, naturalmente, um processo histórico longo e desigual, no entanto, ele cristaliza uma série de distinções conceituais fundamentais: entre público e privado, Estado e sociedade ${ }^{41}$.

Todavia, nem a comunidade limitada nem a soberania política explicam completamente o condicionamento material da unificação política. Para exemplificar essa questão, a recuperação por Schmitt do significado original do termo grego "nomos", como unidade territorial do direito e do espaço, é bastante instrutiva ${ }^{42}$. O significado da soberania clássica do Estado na tradição eurocêntrica é, de acordo com Schmitt, uma ordem concreta baseada na apropriação territorial e na reivindicação de título no exterior. São esses nomos, entendidos como uma "tomada” de terra, que subscrevem os fundamentos do direito público e que fornecem as condições para a "autonomia do político"43.

Esse fundamento material da unidade política em uma apropriação inicial da terra coloca-o em contato com uma tradição estabelecida e crítica da economia política, a qual apresenta esse elemento inicial como a formação e o condicionamento do desenvolvimento econômico capitalista: a “acumulação prévia” de Adam Smith, a “acumulação original” ou “primitiva” de Marx, o “capitalismo político” de Max Weber. Hannah Arendt, seguindo Rosa Luxemburg, ao descrever o imperialismo do final do século XIX, qualifica essa apropriação de "simplesmente roubo"44.

Com esse elemento político-econômico adicional, a unidade política parece estar em condições muito menos firmes do que o nomos de Schmitt. Ela surge nas areias em movimento de desenvolvimento material, em relação à produção e distribuição (e não apenas a tomada) da terra, bem como à organização material de (desiguais) relações sociais baseadas no trabalho e no dinheiro. Luxemburg diretamente reativou o significado adicional de nomos como nahme em relação ao imperialismo moderno, apanhado em sua análise do Landnahme imperial não só como um ato de “conquista de terras”, mas também como um processo de expansão do mercado capitalista ${ }^{45}$. O foco meramente em uma conquista inicial de terra oculta o desenvolvimento material desse primeiro nomos moderno. Como recentemente observou David Harvey, o Estado moderno não está apenas baseado em uma “captura” inicial, mas seu caráter de classe (relação de dominação) é mantido por meio de processos reiterados de “acumulação por desapropriação”. Isso ocorre não só por meio da

\footnotetext{
${ }^{41}$ Cf. Loughlin: ‘Ten Tenets of Sovereignty’ in N. Walker (ed) Sovereignty in Transition (Hart, 2003) 55-86.

${ }^{42}$ Cf. Schmitt, supra n. 36.

43 Ibid.

${ }^{44}$ Cf. H. Arendt, Origins of Totalitarianism (Harcourt, 1968) 148.

45 Schmitt omite a discussão da atualização do marxismo por Luxemburg para a era imperial; no entanto, ele aborda brevemente a ideia marxista de apropriação original em 'Nomos of the Earth', 333-334, acrescentando que, "se a essência do imperialismo está na precedência da apropriação diante da distribuição e produção, então, uma doutrina como a expropriação dos expropriadores é obviamente o imperialismo mais forte, porque é o mais moderno”.
} 
força e fraude, mas também mediante processos formais de privatização e medidas de austeridade que gerenciam a relação entre dívida pública e privada ${ }^{46}$.

A formação da unidade política ocorre, portanto, em relação não (somente) com o momento simbólico do desencanto religioso, nem (somente) com o ato concreto de apropriação territorial, mas com a organização política e econômica e a reorganização das relações sociais ao longo do tempo e do espaço. Isso inclui o processo de construção da comunidade e reconhecimento soberano, mas se estende também às relações econômicas políticas de desigualdade material e dominação, bem como de reprodução e redistribuição social.

Portanto, a unidade política do Estado encontra-se em relação diacrônica com a dinâmica material tanto doméstica como geopolítica. A partir deste ponto de vista, o processo de unificação política está internamente relacionado com a transformação do Estado, de uma organização de poder feudal para uma capitalista (e posteriormente imperial). Ele depende de relações entre capital e trabalho ou centro e periferia. Logo, a unificação política parece uma dinâmica histórica contingente e desigual baseada em fatores concretos que são reproduzidos politicamente, não só porque o Estado tem que providenciar segurança e bem-estar, mas também porque as reivindicações de soberania popular, comunidade nacional e dominação imperial (bem como as reivindicações anti-imperialistas e de classe por emancipação ou autodeterminação) são características de demandas materiais por expansão ou inclusão. O surgimento e a manutenção da unidade política, obviamente, seguem caminhos de desenvolvimento político e econômico distintos tanto na relação doméstica como geopolítica ${ }^{47}$. Isso é entendido não apenas como uma forma de organizar a economia, mas como parte integrante da organização das relações entre o Estado e a sociedade e entre os próprios Estados ${ }^{48}$.

A lógica territorial e comunitária da unidade política e a lógica capitalista da expansão imperialista do mercado doméstico encontram-se em um relacionamento de tensão. A própria unidade política é ameaçada pela percepção de que a ordenação constitucional ocorre com base em uma bruta dominação econômica, seja de uma classe doméstica dominante, de um Estado dominante dentro de uma federação ou de um poder imperial. Para que a ordenação constitucional produza uma unidade política relativamente estável, tal como um Estado-nação ou uma união supranacional, e não apenas

\footnotetext{
${ }^{46}$ D. Harvey, The New Imperialism (Oxford University Press, 2003); M. Blyth, Austerity: The History of a Dangerous Idea (Oxford University Press, 2013).

${ }^{47}$ Como sugerido em outra parte por Loughlin, baseando-se em Lindahl, e dando uma reviravolta dinâmica ao conceito de nomos, "o ato de fundação pode ser entendido como tal somente após o evento: a apropriação original [...] pode ser identificada como fundacional apenas quando o segundo e o terceiro aspectos do nomos (distribuição e produção) são institucionalizados”. Foundations, 29.

${ }^{48}$ Cf. W. Streeck, 'Taking Capitalism Seriously: Towards an Institutional Approach to Contemporary Political Economy' (2011) Socio-Economic Review 137-167.
} 
uma ordem de dominação econômica, como o comitê executivo da burguesia ou um bloco hegemônico de Estados credores, a separação de esferas políticas e econômicas é indispensável.

A relação interna entre a formação da unidade política e a dominação econômica é conceitualmente significativa na medida em que o Estado-nação moderno caracteriza-se tipicamente na teoria constitucional como uma forma política em que a autoridade não depende da fusão explícita do poder político e econômico: é a autonomia relativa do político a partir do econômico que sustenta a autoridade constitucional moderna, distinguindo-a das formas políticas anteriores, tanto medievais quanto antigas ${ }^{49}$. Mas, se o Estado moderno como nomos representa não apenas uma apropriação formal (ou bruta) da terra, mas - como um ordenamento dinâmico concreto - uma transformação das relações sociais e geopolíticas mediante a mercantilização da terra, do trabalho e do dinheiro com base em formas de dominação, o vínculo íntimo entre o político e o material no processo de ordenação constitucional é revelado 50 .

A formação do Estado moderno está internamente relacionada com uma dinâmica de igualdade formal (unidade política) e desigualdade material. Isso requer um modo relativamente autônomo de autoridade política, bem como os meios para garantir o fluxo de acumulação de capital por meio das estruturas do bourgeois Rechtsstaat e outras formas (e modos informais) de dominação geopolítica e expansão do mercado ${ }^{51}$. A unidade política requer e constrói uma comunidade limitada e uma soberania política, mas ambas são feitas possíveis e ameaçadas por relações materiais de desigualdade e dominação. A unidade política é, portanto, um processo altamente instável, e essa instabilidade se manifesta na constituição material que parcialmente ordena.

\section{B) INSTITUIÇÕES}

O esboço da formação dinâmica da unidade política não capta completamente o substrato da constituição material no processo de ordenação constitucional. A formação da unidade política e da própria constituição depende do trabalho das instituições, incluindo, entre outras, os órgãos governamentais formais, como cortes, parlamentos, executivos, bancos centrais; dependem também de instituições não governamentais, informais, societárias e culturais, tais como: família, idioma,

\footnotetext{
${ }^{49}$ Cf. Loughlin, supra n. 37. Veja: E. Wood, From Lords to Citizens: A Social History of Western Political Thought (Verso, 2011).

50 Cf. R. Luxemburg, The Accumulation of Capital: A Contribution to an Economic Explanation of Imperialism (Routledge, 2003 (1913)). Estas são as três “mercadorias fictícias”; mercantilização da qual o pensamento de Ponanyi leva a um duplo movimento de reação social ou reincorporação, potencialmente desestabilizando a ordem constitucional. Veja: K. Polanyi, The Great Transformation (Beacon Press, 1944).

${ }^{51}$ Cf. K. Polanyi The Great Transformation: The Political and Economic Origins of Our Time (Beacon Press, 1944).
} 
sindicatos, mitos e símbolos. Elas têm um papel unificador e exercitam uma força ordenadora, mas, evidentemente, gozam de certa autonomia da lógica da unidade política, bem como das condições materiais do desenvolvimento econômico ${ }^{52}$.

As instituições são os “objetos” que compõem a constituição material (em termos aristotélicos, sua causa material). Elas são produzidas por meio de interações sociais e desenvolvem sua própria normatividade institucional, à maneira de costumes ou convenções. O estudo da constituição material requer uma análise das instituições cuja normatividade e coesão integrativa mantêm a aderência social, permitindo que uma ordem social relativamente estável surja como uma ordem constitucional.

Essa ideia é altamente relacionada com a tradição do institucionalismo jurídico e do pensamento da ordem concreta. O trabalho de Carl Schmitt é novamente instrutivo nesse ponto. Ele chegou à conclusão que uma comunidade política existe somente na medida em que há uma ligação orgânica entre o público da sociedade, a autocompreensão institucional e a forma como os membros da sociedade moldam suas vidas diárias. Isso significa que uma determinada forma política não pode ser mantida a menos que um determinado conjunto de instituições (que reflitam determinadas práticas sociais) seja constantemente nutrido e protegido. Uma comunidade política existe, portanto, apenas na medida em que seu direito público mantém condições para a proteção de certas instituições, como o casamento e a família, o aparato militar, a burocracia, o sistema monetário e assim por diante $\mathrm{e}^{53}$.

Não se trata de que algumas práticas sociais naturalmente dão origem e formam uma comunidade política. Não existe uma conexão natural entre uma determinada comunidade política e as instituições que a ordem jurídica dessa comunidade protege. A sociedade, como entendido por Schmitt, é intrinsecamente plural e os atores sociais tendem a produzir mais respostas normativas a problemas práticos; isso, como observou Schmitt no final de Weimar, sublinha uma certa instabilidade na democracia representativa e, na verdade, na própria Constituição quando ela tenta proteger valores substantivos diversos e potencialmente concorrentes.

Schmitt prevê uma divisão de trabalho entre as instituições jurídicas e políticas. Em termos gerais, o direito formal é o conjunto de regras e cláusulas gerais que definem as instituições e garantem que os padrões de conduta sancionados pelo Estado sejam seguidos. O poder político exerce um trabalho seletivo: os governantes políticos identificam as instituições que são propícias à homogeneidade básica da população. Essa seleção é, naturalmente, até certo ponto contextual. No entanto, com base no interesse de Schmitt pela homogeneidade, é preciso buscar uma solução

${ }^{52}$ Cf. S. Romano, The Legal Order (Routledge, 2017).

${ }^{53}$ Cf. M. Croce e A. Salvatore, The Legal Theory of Carl Schmitt (Routledge, 2012). 
constitucional que permita a criação e preservação dessa homogeneidade e da ordem concreta que ela sustenta. O risco de potenciais conflitos intrassociais que a reprodução da sociedade traz consigo (mas que só pode ser entendido plenamente quando aprofundamos na terceira e quarta camadas da constituição material) deve ser controlado, de acordo com Schmitt, apelando para a homogeneidade relativa do povo, defendida, se necessário, pela aniquilação dos inimigos da constituição. Portanto, Schmitt assume uma conexão necessária e direta entre um governante político (por meio de seu representante político) e a sociedade que ele governa. Ou seja, deve haver instituições que se ocupem lealmente de aplicar os critérios que o governante político concebe como necessários para proteger e promover instituições sociais e a sua identidade ${ }^{54}$.

O constitucionalismo material, no entanto, rejeita esse relato personalista e conservador das instituições; o próprio institucionalismo jurídico fornece recursos suficientes para evitar essa armadilha redutora. A ordenação constitucional, como mencionado acima, é um processo dinâmico de vir a ser e isso significa, a partir de uma perspectiva constitucional material, a possibilidade de adaptação (dentro de certos limites) aos desafios e conflitos internos ${ }^{55}$. Em certas condições, os conflitos podem nutrir a constituição material fortalecendo as instituições envolvidas em sua gestão ou adiamento. As instituições, incluindo as constitucionais formais, raramente resolvem os conflitos como esses, mas elas podem impedir que eles degenerem em hostilidade absoluta ou em colapso político e social, atuando como válvulas de pressão para energias conflituosas. Além disso, em razão do fato de que há espaço para novas interpretações da normatividade de uma instituição e para que emerjam novas instituições, a constituição material é mais flexível e dinâmica que a prevista por Schmitt, mesmo depois de sua virada institucionalista.

As instituições, entretanto, também são realizações frágeis. Elas estão sob pressão tanto de cima, por exemplo, quando entram em conflito com as forças de unificação política ou de expansão econômica material e, a partir de baixo, quando as relações sociais emergem de uma maneira que ameaça sua estabilidade contínua. A confiança nas instituições pode então ser corroída até mesmo fatalmente.

A história do direito constitucional na Europa na segunda metade do século XX é, por exemplo, uma reconstrução institucional extraordinária com base em novas formas de accountability política, muitas vezes não majoritárias ou “tecnocráticas”. Do predomínio das cortes constitucionais ao aumento mais recente dos bancos centrais independentes, isso reflete um conjunto distinto de crenças sobre a mediação institucional do relacionamento do governo, crenças que, em parte, foram

\footnotetext{
54 Ibid., 30-45.

${ }^{55}$ Para mais reflexões sobre esse ponto veja a seção $n^{\circ} 4$, abaixo.
} 
formadas por reação à quebra das instituições liberais no período entre guerras. Esse processo de fortalecimento institucional continua no nível supranacional e internacional, por meio do projeto de integração europeia e da Convenção Europeia dos Direitos Humanos. Como as instituições adquirem uma certa vida própria, mais notavelmente no caso da UE, a sua desincorporação social coloca problemas distintos de legitimidade constitucional. Com a proliferação de instituições, acrescentamse camadas de complexidade e pontos de conflito crescentes, na interface entre instituições nacionais e supranacionais (mais evidentemente entre as autoridades judiciais no âmbito nacional e europeu), mas também entre lógicas conflitantes de racionalidade, como legalidade e racionalidade do mercado, e oposição às forças políticas e sociais ${ }^{56}$.

Além disso, como a avaliação do próximo fator de ordenação da constituição material deixará claro, a alusão de Schmitt à homogeneidade, na melhor das hipóteses, subestima e, no pior caso, esconde as relações sociais heterogêneas e os conflitos materiais que condicionam o desenvolvimento constitucional. Uma vez que as instituições podem mediar os conflitos entre o Estado e a sociedade, mas não os resolvem, precisamos recorrer a um outro fator de ordenação, o das relações sociais "horizontais" que pertencem entre os indivíduos que constituem a unidade política e que compõem o poder institucional da sociedade.

Portanto, as próprias instituições são baseadas em um poder institucional relativamente autônomo que entra em erupção da sociedade e do imaginário social ${ }^{57}$. O poder institucional reflete não só os conflitos sociais, mas também a cooperação e a solidariedade.

\section{C) RELAÇÕES SOCIAIS}

O material mais básico de uma constituição encontra-se sob a categoria de instituições. Ela consiste em interação social subjetiva e conflito social, os quais são condicionados pela solidariedade interpessoal e pela competição. O conflito e a interação social são mitigados pela função unificadora das instituições e pela unidade política do próprio Estado, mas não (talvez nunca) são totalmente ou finalmente resolvidos.

Continua a ser uma pergunta em aberto a extensão em que as relações sociais (e, por sua vez, as instituições e a unidade política que constituem) são condicionadas por formas específicas de consciência e dominação de classes - em que a classe não precisa ser determinada pela apropriação dos meios de produção, como entendido no marxismo clássico. Significa uma vantagem importante

\footnotetext{
${ }^{56}$ Cf. The OMT saga, Special Issue of the German Law Journal, vol. 15, n 2 (2015).

${ }^{57}$ Cf. C. Castoriadis, The Imaginary Institution of Society, tr, K. Blamey (MIT Press, 1997).
} 
da constituição material sobre a teoria puramente política do direito (ou o constitucionalismo formal) que o relacionamento e a distância entre governantes e governados e entre os governados entre si não sejam representados como puramente formais. Em sociedades que se consideram democráticas ou, em alguma medida, autogovernadas, a ideia de uma distância entre governantes e governados é, na verdade, antitética à ordenação constitucional, pelo menos à sua autoimagem como sociedade democrática. Isso não quer dizer que possa haver uma identidade pura entre governantes e governados, mas que a relação entre governantes e governados é material e dinâmica.

Os atores constitucionais não devem, portanto, ser reduzidos ao status de constituídos ou objetos abstratos (ou instituições). Em vez disso, o estudo da constituição material concentra-se igualmente no processo de “subjetivação”, enfatizando a formação de atores políticos coletivos e sua contribuição para a mudança constitucional. Esta é também uma questão de identificação: predominantemente, o indivíduo identifica a si mesmo como parte de uma determinada classe, nação, etnia, como cidadão, empresário ou consumidor? Ou qual dessas combinações?

Os constitucionalistas podem retornar aos antigos conceitos de estudos sociologicamente sensíveis da constituição para integrar os processos de subjetivação política na análise. A produção e a reprodução substantivas da constituição material são o resultado de uma série de conflitos sociais, políticos e geopolíticos por meio dos quais as subjetividades coletivas são forjadas. Os sujeitos coletivos fornecem o ímpeto para a dinâmica material da formação política e do desenvolvimento institucional. Precisamos, portanto, mudar o foco constitucional do indivíduo abstrato (ou instituição) para esses processos de subjetivação, com seu potencial de inclusão e exclusão.

Um ponto de partida útil para aprofundar esse fator é o trabalho de institucionalistas italianos como Santi Romano e Costantino Mortati, bem como aqueles que trabalham na tradição de Gramsci ${ }^{58}$. Se o surgimento de uma nova constituição material só é possível mediante a ação política do príncipe (na perspectiva de Maquiavel) ou de um equivalente (na versão de Gramsci, o partido político) ${ }^{59}$, isso depende de processos de subjetivação seletiva e deve ser sustentado por uma série de sujeitos políticos organizados. O político aqui deve ser lido em sentido lato sensu e, de forma alguma, limitado aos partidos políticos ou formas já institucionalizadas. Ele deve incluir grupos informais e movimentos sociais, bem como forças sociais antissistêmicas e desordenadas.

\footnotetext{
58 S. Romano, supra n. 48: C. Mortati, La Costituzione in senso materiale, supra n. 8; A. Gramsci, Prison Notebooks (Columbia University Press, 1992. Para uma visão geral que enfatiza os aspectos de continuidade entre esses autores: R. Esposito, Living Thought (Stanford University Press, 2014).

${ }^{59}$ A. Gramsci, Selection from the Prison Notebooks (International Publishers, 1971) 253.
} 
Como observamos em nossas premissas metodológicas, embora o estudo da economia política seja crucial para a compreensão da formação e reprodução material da sociedade, a estrutura da constituição material não é determinada economicamente. Assim, ainda que o surgimento de uma constituição material esteja claramente interligado com uma organização concreta da economia política, o estudo da constituição material não pode ser reduzido à base econômica subjacente ${ }^{60}$, isto é, a base econômica não deve ser apresentada como uma supradeterminação da constituição material; em vez disso, eles são inter-relacionados. A economia política encontra-se acima de uma ordem existente e sua trajetória é, antes de tudo, promovida por uma série de ações políticas, inclusive aquelas que representam a formação da unidade política. Os sujeitos políticos são, portanto, essenciais na formação e na preservação de uma economia política particular, bem como no fomento à mudança ao pressionar a reforma da estrutura político-econômica.

O constitucionalista alemão Herman Heller, interlocutor negligenciado de Kelsen e Schmitt, que ofereceu uma terceira alternativa entre o normativismo e o decisionismo, indica essa visão dinâmica do desenvolvimento constitucional baseada em relações sociais materiais. Ao apresentar a lei e a política na relação dialética na constituição do governo, Heller argumenta que essa relação não pode ser abstraída da dimensão social, no sentido de que a unidade política - o primeiro fator em qualquer ordenação constitucional - não depende apenas do apoio institucional para que ela possa sobreviver, mas também requer um certo grau de igualdade social, ou pelo menos a sua probabilidade $^{61}$

De acordo com Heller, a constituição é principalmente uma ordem social, formada não só por ações legislativas, tradições e conveniência política, mas também por constelações de poder social e econômico ${ }^{62}$. Historicamente, a constituição pode então aparecer como um mero modus vivendi, resultado de um compromisso político ou de um equilíbrio fortuito de interesses sociais e econômicos. Para Heller, no entanto, o conteúdo da constituição substantiva não é, contra Schmitt, expresso por uma decisão solitária ou mesmo uma pluralidade de decisões concretas, mas tem uma qualidade ética ${ }^{63}$.

Para Heller, a autoridade da constituição não está no sentido (kelseniano) de autorização por uma norma previamente válida (que só levaria à regressão infinita fechada pela Grundnorm), mas

\footnotetext{
${ }^{60}$ Exemplo dessa forma de redutivismo: C. Beard, An Economic Interpretation of the Constitution of the United States (MacMillan, 1913).

61 H. Heller, 'Political Democracy and Social Homogeneity' in A. Jacobson and B. Schlink (eds) Weimar: A Jurisprudence of Crisis (Berkeley, University of California Press, 2000) 265. Veja também: Dyzenhaus, 'Hermann Heller and the Legitimacy of Legality' (1996) 16 Oxford Journal of Legal Studies 641-666.

${ }^{62}$ Heller, ibid, 275-6.

${ }^{63}$ Ibid, 277.
} 
tem por base princípios éticos ao serviço do bem comum. Rejeitando o “poder sem norma” de Schmitt e a "norma impotente" de Kelsen, Heller argumenta ter encontrado um meio caminho. Ele argumenta que a constituição exige pelo menos uma fração decisiva daqueles sujeitos ao seu poder, não apenas para cumprir a constituição por autointeresse ou hábito, mas para aceitá-la como vinculante. Embora Heller não a descreva usando precisamente esses termos, ela exige que uma proporção adote um “ponto de vista interno”. Heller também não explica qual proporção da população seria decisiva ou o que a torna decisiva - ou mesmo o que uma “fração” da população significa ${ }^{64}$.

Ao introduzir essa perspectiva de reconhecimento e aceitação social, Heller é levado a enfrentar uma teoria da democracia. “A lei da democracia”, afinal, diz Heller, “atribui a formação do poder do Estado ao povo”65. Isso, obviamente, foi claramente o caso da Constituição de Weimar. Embora a democracia nunca consistirá na “identidade” dos governantes e governados, a questão da homogeneidade social na democracia é elevada em relação direta com a substância ética - o "bem comum” - da política e com sua própria viabilidade ${ }^{66}$.

Tanto a natureza concreta como a fragilidade dessa qualidade ética são evidentes quando se passa da teoria do estado de Heller para seu comentário político. Heller deixa claro que essa qualidade não deve ser apresentada ou defendida em termos abstratos ou existenciais. Afirmando que a distinção “amigo-inimigo” de Schmitt ignora a dinâmica da formação de vontade política, Heller argumenta que a "homogeneidade” é algo que deve ser formado diariamente, aprovando a famosa descrição de Renan do nacionalismo como "un plebiscite de toujours" 67 . A distinção básica amigo/inimigo de Schmitt sobre a qual o conceito do político depende não é suficientemente política, pois tem a característica de ser “de cima para baixo”. Isso entra em contradição direta com a democracia, “que deveria supostamente ser um processo consciente da formação da unidade política de baixo para cima $[\ldots]^{\text {"68 }}$.

A unidade política não é um simples fato de reconhecimento existencial do "eu” e do "outro", do “nós” e “eles”; pelo contrário, essas posições e a própria unidade política são formadas, construídas e mediadas pelo processo constitucional na canalização de reivindicações concorrentes sobre o bem

\footnotetext{
${ }^{64}$ Cf. M. Wilkinson, 'Is Law Morally Risky? Alienation, Acceptance and Hart’s Concept of Law’ (2010) Oxford Journal of Legal Studies 441-466.

65 Ibid, 273.

${ }^{66}$ Essa insistência na homogeneidade é feita (de maneiras diferentes) por todos esses três, não apenas Schmitt e Heller, mas também Kelsen argumentando que uma certa homogeneidade é necessária para a política democrática. Kelsen, no entanto, rejeita explicitamente a afirmação de que a democracia requer igualdade socioeconômica. Veja: H. Kelsen, 'On the Essence and Value of Democracy' in A. Jacobson and B. Schlink (eds), acima.

${ }^{67}$ Ibid, 260.

68 Ibid.
} 
comum. Sua essência, no entanto, permanece evasiva, resistente a qualquer análise ou resolução empírica direta ${ }^{69}$. Embora seja necessária uma crença na homogeneidade social para facilitar e sustentar uma ordem democrática relativamente estável, isso não significa a "abolição da estrutura social antagônica”70.

Heller enfatiza que no sistema democrático as instituições e os partidos políticos, em particular, são essenciais para unificar as numerosas vontades dos cidadãos $^{71}$. No entanto, a “homogeneidade” é, em última análise, uma categoria social e econômica em vez de uma questão espiritual, cultural ou étnica ${ }^{72}$. O que é decisivo não é a superestrutura intelectual ou ideológica, nem mesmo os canais institucionais de resolução de conflitos, mas a realidade das disparidades econômicas. Ele reconhece que a burguesia como classe tentará ressuscitar ideologias, inclusive as do nacionalismo e da monarquia, a fim de manter sua própria posição de poder no eterno "ciclo das elites”. "Sem homogeneidade social”, advertiu Heller, “a igualdade formal mais radical se torna a desigualdade mais radical, e a democracia formal se torna a ditadura da classe governante"73.

A constituição então está em uma relação interna com a ordem social material (bem como a unidade política e as instituições), entendidas em termos de relações sociais informais e subjetividades interpessoais que se desenvolvem ao longo do tempo. Se elas se tornam materialmente heterogêneas, por meio do aumento da desigualdade social, a própria ordenação constitucional pode tornar-se difícil ou mesmo impossível.

\section{D) OBJETIVOS POLÍTICOS FUNDAMENTAIS}

Existe um fator final que condiciona a ordem constitucional e que pode até mesmo mantê-la funcionando apesar dos conflitos sociais, compensando a desunião política e a fraqueza institucional: isso é capturado mediante um telos material (ou conjunto de teloi). Os sujeitos e instituições constitucionais projetam certos objetivos políticos fundamentais ou até mesmo uma "finalidade”

\footnotetext{
${ }^{69}$ Heller: “Não se pode dizer definitivamente como essa ‘consciência de nós’ é produzida e destruída. Todas as tentativas de encontrar o impulso para essa consciência em uma única esfera da vida falharam e devem falhar. Tudo o que podemos saber com razão é que, em cada época, emerge uma correspondência entre o ser social e a consciência - em outras palavras, uma forma social”, ibid, 261.

${ }^{70}$ Ibid, 260.

${ }^{71}$ Ibid.

72 Ibid, 261.

${ }^{73}$ Ibid, 262 (um fator que permite a Heller distinguir o problema social europeu da “Questão Negra” na América). Ele observa que "nada é mais característico da disparidade social que ameaça nossa democracia que a tentativa de transformar a disparidade econômica em uma disparidade antropológica”, ibid, 264.
} 
futura e excluem ou omitem outros. A constituição formal mantém-se em relação com esses objetivos, às vezes em tensão, outras em harmonia.

A criação da unidade política, a formação das instituições e o desenvolvimento das relações sociais giram em torno da possibilidade de moldar uma trajetória sobre a constituição material. No entanto, a trajetória de uma pode entrar em conflito com a trajetória impressa por outros fatores de ordenação da constituição material. A constituição, portanto, evoluirá de acordo com a complexa dinâmica material da mudança política, institucional e social. Também evoluirá em relação à trajetória estabelecida na constituição formal e sua interpretação por órgãos e instituições oficiais.

O conjunto de objetivos constitucionais explícitos e implícitos reflete a composição das forças sociais, políticas e geopolíticas dominantes que atuam como um catalisador. Esta perspectiva oferece uma alternativa às clássicas doutrinas constitucionais que, de acordo com a filosofia política moderna, enfatiza a origem da constituição como se contivesse dentro de si a energia para a criação e o desenvolvimento da ordem constitucional. Essa origem aparece então como externa, tanto para a sociedade como para a própria ordem constitucional. Como no caso de um dispositivo mecânico, o ato original colocaria a constituição em movimento a partir do exterior, atuando como um catalisador externo.

O pensamento do contrato social que influenciou uma grande teorização constitucional coloca a criação da sociedade e as condições da ordem constitucional a partir de uma perspectiva externa, isto é, de uma condição pré-política, hipotética ou “natural”. As relações sociais que pertencem ao momento originário (seja o estado da natureza ou a posição original) são então ocultas, anuladas em virtude de um experimento de pensamento, mas que atua como lente distorcida porque despolitiza as condições materiais existentes e as relações sociais. Uma vez incorporada para o direito constitucional, também legitima a retirada de decisões dos processos políticos e sociais ordinários de contestação ${ }^{74}$. Em outras palavras, a constituição material está inteiramente (e deliberadamente) escondida nessa perspectiva.

O decisionismo, apesar de ser radicalmente diferente do contrato social em suas perspectivas formais, assume um ponto de partida semelhante: a origem da ordem jurídica, o "big bang” que contém as sementes para seu desenvolvimento posterior encontra-se em uma posição exterior à própria ordem. O poder constituinte é concebido como causa incausata, criando a partir do nada uma nova ordem, uma qualidade que pode retornar por meio do estado de exceção. A origem também

\footnotetext{
${ }^{74}$ Cf. S. Wolin, ‘The Liberal/Democratic Divide: on Rawl’s Political Liberalism’ (1996) 24 Political Theory 97-119.
} 
pode oferecer uma posição conservadora, defendendo a constituição de forma reativa contra mudanças políticas e sociais ou contra a agitação para tal mudança.

O estudo da constituição material toma uma abordagem diferente. A formação social sempre é política; a constituição não é ou não pode sair do nada ou de um estado de natureza. O que torna possível a formação social em primeiro lugar, dentro de um espaço determinado e por intermédio da mediação de instituições já existentes, é a convergência de certas forças políticas e sociais sobre uma série de objetivos políticos básicos e a capacidade de afirmá-los. O estado de exceção, então, existe dentro da constituição entendida amplamente como uma constituição material.

Mediante a associação política, diferentes forças sociais tendem a comprometer-se a perseguir objetivos distintos por diferentes razões e interesses. Ao convergir sobre esses objetivos, as forças hegemônicas podem imprimir uma trajetória particular sobre a constituição material. As condições que tornam isso possível são abordadas por Poulantzas e sua concepção relacional de poder político. Poulantzas viu que a constituição material é formada pela “condensação das forças sociais” em torno de um conjunto de objetivos políticos ${ }^{75}$. Uma versão de sua pesquisa pode orientar o estudo da constituição material: "por que as democracias liberais decidiram se dar particularmente essas constituições políticas e não outras?” Essas forças podem ser tanto informais como formais, elas podem ser predominantemente domésticas, mas também podem ser um bloco hegemônico dentro de uma federação ou uma formação geopolítica.

Ao mesmo tempo, a teleologia da constituição material, desenvolvendo-se de acordo com sua própria lógica (relativamente autônoma), reformula a identidade das forças hegemônicas ao longo do tempo. A trajetória da constituição material está, portanto, condicionada pela objetivação de suas metas: uma objetivação então impõe limites à maneira de alcançá-las ${ }^{76}$. Em outras palavras, as forças hegemônicas que sustentam a constituição material não são inteiramente livres para mudar, sem limites ou restrições. Além disso, a formulação e a busca de objetivos políticos fundamentais podem gerar consequências imprevisíveis, contradições ou paradoxos no desenrolar da constituição material. Em suma, na busca real de objetivos políticos comuns, espaços imprevistos podem abrir-se para novas subjetividades ou mudanças nas alianças, e com efeitos potencialmente disruptivos.

O nível de intensidade do apoio social e institucional geral é uma indicação importante da força de uma constituição material. Quanto mais forte o apoio aos objetivos políticos (ou mesmo a finalidade) de um regime, mais sólida é a sua constituição material. Sem essa trajetória, a constituição

\footnotetext{
${ }^{75}$ Poulantzas, supra n. 32.

${ }^{76}$ R. Cover, 'Nomos and Narrative’ (1983) 97 Harvard Law Review 4, 44-46.
} 
material terá dificuldade em manter-se unida, particularmente quando os objetivos se conflitam diretamente.

É importante notar ainda que não haverá necessariamente convergência nesses objetivos. A divergência irá ocorrer e a luta existencial às vezes ocorrerá. De fato, como sugerido acima, no contexto da dinâmica política capitalista baseada na competição, conflito de classes e dominação imperial, bem como da dinâmica oposta baseada na solidariedade, cooperação e emancipação, a divergência é inevitável. Em certos momentos conjunturais, em que as forças de oposição se combinam para apresentar uma crise constitucional, sem uma força hegemônica prevalecente, haverá maior fluidez de possibilidades e novas trajetórias provavelmente surgirão, juntamente com novas forças hegemônicas.

A noção de uma teleologia constitucional é antiga. Como Aristóteles discute na Política, a “constituição [...] revela o objetivo da cidade-Estado"77. Isso pode parecer enigmático, mas, no mínimo, o objetivo implícito é a sobrevivência do Estado, do governo ou do projeto de unidade política. Todavia, com frequência, e cada vez mais, as próprias constituições formais apresentam mais objetivos específicos ou anunciam explicitamente um telos (ou conjunto de teloi). Esse é o caso de muitas constituições modernas, particularmente as instituídas na Europa Ocidental na sequência da Segunda Guerra Mundial, que promovem valores particulares, embora ainda vagos, como a democracia, o federalismo, os direitos humanos ou o bem-estar social.

Um caso ilustrativo, devido à sua origem em condições materiais bem documentadas, bem como às dificuldades existenciais que enfrenta agora, é a constituição da União Europeia (a sua constituição formal é famosa como uma “carta constitucional”). Uma teleologia animadora caracterizou o projeto de integração desde a sua criação, com o preâmbulo de "uma união cada vez mais estreita entre os povos da Europa”, com a sua marca desde o Tratado de Roma. A discussão sobre a "finalidade" do projeto europeu foi até mesmo um antecessor público significativo do malfadado experimento constitucional ${ }^{78}$. Mas, como afirma Étienne Balibar, refletindo sobre o nascimento da UE no Tratado de Maastricht, o que é extraordinário é a natureza explícita e detalhada de seus objetivos constitucionais político-econômicos:

A UE em seu momento constitutivo (Maastricht) foi dotada de uma quase-constituição [...] onde, pela primeira vez nesta parte do mundo [...] um princípio de economia política derivado de um discurso ideológico específico (a saber, a desregulação neoliberal e a

\footnotetext{
${ }_{77}$ Aristotles, Politics [I.1.1252a1-7], [IV.1.1289a17-18].

${ }^{78}$ Cf. J. Fischer, 'From confederacy to federation: thoughts on the finality of European integration' in C. Joerges, Y. Meny and J. H. H. Weiler (eds) What Kind of Constitution for What Kind of Polity: Responses to Joschka Fischer (Jean Monnet Program Online Papers, 2001).
} 
concorrência irrestrita, a princípio para produzir “alocação ótima de recursos” e redistribuição "justa”) foi apresentado como a regra soberana que todos os Estados membros deveriam implementar em suas políticas nacionais sob estreita vigilância dos órgãos federais (ou quase-federais) da União $[\ldots]^{79}$.

No entanto, mediante a recente crise do euro, esse conjunto de objetivos formais e informais, constitucionalizados desde Maastricht, que gira em torno das exigências ordoliberais de estabilidade de preços, disciplina fiscal e prevenção do risco moral, entra em conflito com o telos implícito de integração e, especificamente, da "irreversibilidade" da moeda ${ }^{80}$. Nos momentos de maior tensão entre o telos da "irreversibilidade" da moeda e as normas básicas da "estabilidade” monetária, o “Grexit” involuntário é então discutido como forma de estabilizar a constituição material da Zona do Euro $^{81}$. Não há um método formal de sair (voluntariamente ou de outra forma) da moeda única, mas há poucas dúvidas de que o equilíbrio material de forças condiciona as possibilidades políticas disponíveis para Atenas. Os blocos hegemônicos entre os Estados credores, portanto, podem mudar o equilíbrio do poder constitucional material e alterar o processo dinâmico da ordenação constitucional.

Esse foco em objetivos políticos particulares lança luzes sobre a natureza da arte de governar, que, como observado por Mortati, não pode ser reduzida às outras três funções constitucionais clássicas $^{82}$. Na visão de Mortati, a função governante subordina as outras três funções, em vez de ser totalmente explicada por eles. De fato, as três funções-padrão só têm sentido de direção por meio do espelho da própria função governante, e essa trajetória governante é determinada por objetivos políticos fundamentais ${ }^{83}$.

A noção de funções aqui não deve ser mal interpretada. Conforme sugerido acima, ao contrastar nossa abordagem ao constitucionalismo sociológico, a dimensão teleológica da arte de governar é moldada pela ação política em vez de pela funcionalidade pura. Essa não é uma distinção pedante porque traz consigo importantes consequências para a compreensão do processo de ordenação constitucional. Pode ser possível que uma determinada instituição em uma determinada ordem constitucional tenha o poder e a responsabilidade de orientar a função governante para a busca de certos objetivos políticos fundamentais, mas isso é improvável. Com a crescente complexidade das estruturas constitucionais, tornou-se difícil ou mesmo impossível identificar a função de governo em um único objetivo ou instituição única. De fato, uma vez que a finalidade de governar uma

\footnotetext{
${ }^{79}$ E. Balibar, 'The Rise and Fall of the European Union: Temporalities and Teleologies' (2014) Constellations $202-212$.

${ }^{80}$ M. Wilkinson, ‘The Euro is irreversible... Or is it?’ (2015) 16 German Law Journal 1.049-1.072.

${ }^{81}$ Ibid.

${ }^{82}$ C. Mortati, L’ordinamento del governo nel nuovo diritto pubblico italiano (Giuffré, 1931).

${ }^{83}$ Mortati, La costituzione in senso materiale, supra n. 11, capítulo 3.
} 
sociedade não se limita à sua sobrevivência como tal (por exemplo, o Estado apresenta uma certa forma ideal de comunidade), mas inclui a realização ou a preservação de objetivos políticos fundamentais específicos, é mais acurado buscar a teleologia da constituição material em todo o espectro institucional e até mesmo além da dimensão das relações sociais. Em resumo, a teleologia da constituição é material e não formal, em relação a todos os fatores de ordenação da constituição.

\section{A CONSTITUIÇÃO MATERIAL COMO OBJETO DO CONHECIMENTO JURÍDICO}

As considerações desenvolvidas acima foram oferecidas com o objetivo de demonstrar o valor epistêmico do estudo da constituição material. O direito constitucional formal, na análise da constitucional material, não é um mero instrumento nas mãos de forças políticas ou sociais, nem totalmente autônomo. O direito constitucional é incorporado na dinâmica material subjacente. Nesse sentido, a constituição material ressoa claramente com a tradição do pensamento da ordem concreta, mas deve ser dada uma estrutura material mais dinâmica e conflituosa. A força de ordem do direito permaneceria vazia se não fosse apoiada pela unidade política, instituições relativamente poderosas, forças sociais dominantes e animada por um telos (ou teloi) prevalecente. No entanto, a constituição material não é “o que acontece” no sentido de um eventual ocasionismo; em vez disso ela delineia as condições que possibilitam o surgimento de um estado de coisas como uma ordem constitucional. Essas condições podem ser identificadas e analisadas como objetos de conhecimento jurídico.

Os fatores de ordenação encontram-se em relação interna com a constituição formal. Os constitucionalistas não podem ignorar a sua formação, porque eles dão vida à ordem constitucional e condicionam seu desenvolvimento. Cada um dá um senso de direção às normas constitucionais e essa direção é tanto jurídica como política. Por essa razão, em contraste com as versões do constitucionalismo político que retratam o direito e a política como incomensuráveis, na análise material constitucional a relação entre direito e política é interna no sentido de que o direito não pode ser considerado somente como o cinturão de transmissão das decisões políticas que são feitas antes e fora da ordem jurídica. Contrariamente aos positivistas normativos e decisionistas, que postulam que as decisões políticas mais importantes são tomadas antes ou fora do direito, quando a formação de objetivos políticos fundamentais é vista mediante a dimensão material da constituição todas as noções de um processo político autônomo ou de tomada de decisão política casualista se evaporam. Não há nada ocasional ou puramente processual na constituição material.

Em segundo lugar, especificamente em relação ao último fator de ordenação, o nexo entre estrutura constitucional e objetivo político, típico do Estado liberal, é desarticulado porque não existe 
uma determinação singular de um objetivo específico (que, no Estado liberal clássico é sempre a proteção da liberdade individual). Em vez disso, há a abertura a múltiplas variações. Não existem apenas diferentes tipos de Estado no sentido de rotas diferentes para a unidade política formal e para estruturas institucionais, mas também diferentes tipos de Estado em termos dos diferentes objetivos políticos básicos que são buscados.

Uma vez que a constituição material é formada a partir de um conjunto notável de fatores de ordenação, que refletem os contornos de um desenvolvimento societário mais amplo, não é possível assumir que qualquer forma de não obediência ao ordenamento jurídico estabelecido equivale a uma forma de desuso ou mesmo uma mudança da constituição. Por essa razão, a constituição material não deve ser confundida com a ideia de "direito vivo" ou "living constitution”. Esta última é um dispositivo muito mais flexível que insiste em que a mudança social seja mecanicamente (ou organicamente) registrada pela ordem legal, geralmente por meio da interação entre atores particulares e cortes $^{84}$. Uma compreensão material da constituição reconhece que as ordens constitucional e social estão internamente relacionadas (e muitas vezes frágeis) uma com a outra e isso torna a transformação constitucional particularmente mais exigente do que a pura adaptação às mudanças das circunstâncias sociais.

Nem a ênfase dada aos fatores de ordenação sugere que a ordem é facilmente alcançada dentro da constituição material. Pelo contrário, a nossa insistência em movimentos, conflitos e no dinamismo deve sinalizar que a unidade política depende de uma variedade de forças, frequentemente oposicionistas, que se combinam no processo de unificação política, fortalecimento institucional e no movimento de perseguição de objetivos políticos fundamentais. Por essa razão, a constituição pode ser fortalecida pela institucionalização da contestação e do conflito material. Mas esse conflito pode tornar-se ameaçador.

Para melhor entendimento desse processo, podemos estabelecer uma distinção entre dois tipos de conflitos e observar como eles podem ser concebidos a partir da perspectiva da constituição material. Aqui, podemos encontrar um segundo uso epistêmico da constituição material. Um primeiro tipo de conflito, se devidamente institucionalizado, pode levar a uma maior consolidação da ordem constitucional. A constituição é aprimorada se for capaz de gerenciar conflitos e exibir sensibilidade às instâncias sociais, particularmente aquelas que não poderiam ter sido previstas no momento em

\footnotetext{
${ }^{84}$ Essa é uma discussão familiar aos constitucionalistas norte-americanos, pois nos Estados Unidos a oportunidade para atualizar o significado do texto constitucional para a mudança social é mais urgente. Veja: J. Balkin, Living Originalism (Harvard University Press, 2011); D. Strauss, The Living Constitution (Oxford University Press, 2010). No Canadá, isso é conhecido como: “living tree doctrine”: W. Waluchow, A Common Law Theory of Judicial Review: The Living Tree (Cambridge University Press, 2007).
} 
que o projeto constitucional foi iniciado. Isso também permite que a constituição esculpa a sociedade, criando espaço para novas instâncias sociais e novos inputs sociais, o que, por sua vez, concede à constituição material uma certa elasticidade e durabilidade. Isso não significa que tudo possa ser acomodado, mas o movimento animador da constituição material, com seus efeitos em cascata nas instituições, é ativado por esse tipo de gerenciamento de conflitos. Esses conflitos muitas vezes envolvem a pressão exercida pelas forças sociais e políticas nos limites das instituições e dos sujeitos políticos/sociais, e testam sua capacidade para acomodar novas reivindicações. No entanto, esse tipo de conflito não precisa desafiar os objetivos políticos fundamentais da ordem constitucional nem necessariamente dar origem a novos sujeitos constitucionais. Em vez disso, redireciona a dinâmica constitucional existente.

O segundo tipo de conflito ameaça a constituição material testando o núcleo normativo apoiado pelas forças sociais e políticas dominantes. Isso acontece quando a marca dominante não é mais capaz de exercer efeitos penetrantes em toda a comunidade política. Esse pode ser o caso quando as forças governantes já não se juntam em torno dos mesmos objetivos políticos ou quando há contradições internas entre esses objetivos e, por isso, um compromisso não pode ser alcançado. Quando isso acontece, os conflitos deixam de ser produtivos e uma mudança de grande alcance da constituição material (e formal) torna-se urgente. Nessa fase, o estado de exceção atua como um sinal de que a constituição material e a condensação relativa das forças políticas e sociais que o sustentam estão sob uma séria ameaça de dissolução e uma intervenção extraordinária é necessária. Em outras palavras, a exceção não é um evento inesperado que ameaça a partir de fora da normalidade da ordem legal; pelo contrário, a exceção surge de dentro, quando a constituição material está sob ameaça ${ }^{85}$.

Se o estado de exceção for considerado legítimo quando pretende preservar a constituição material $^{86}$, não faz sentido considerá-lo um momento extrajurídico além do conhecimento dos constitucionalistas. Está, pelo contrário, dentro do domínio do conhecimento jurídico. A mesma lógica se desenvolve em outros casos em que o núcleo da constituição material está em jogo. No contexto da União Europeia, por exemplo, isso tornou-se visível no confronto entre as mais altas cortes nacionais em torno da incorporação da legislação da UE em sistemas constitucionais nacionais. Diante do risco de que certas medidas previstas pela legislação da UE poderiam desvendar aspectos do tecido social e, portanto, dos aspectos fundamentais da identidade constitucional nacional, os

\footnotetext{
85 M. Croce, A. Salvatore, 'After Exception: Carl Schmitt's Legal Institutionalism and the Repudiation of Exceptionalism’, in 29 Ratio Juris (2016) 410.

${ }^{86}$ Loughlin, supra n. 21, 280.
} 
juízes sentiram que tinham que estabelecer um limite a ser delineado junto aos princípios constitucionais fundamentais ${ }^{87}$. O desenvolvimento da doutrina de "contralimites" 88 por parte de alguns tribunais constitucionais nacionais pode ser entendido como um exercício de tutela dos aspectos fundamentais da constituição material do Estado-membro sobre a unidade política (identidade nacional), a autoridade institucional e até mesmo as relações sociais ${ }^{89}$. A referência à constituição material (e não formal) ajuda aqui a identificar os limites da revisão ou transformação constitucional. Mas este apelo à tutela da constituição pode ser feito não só por cortes constitucionais, mas outros atores formais e informais, como parlamentos e até mesmo as próprias pessoas, por meio de movimentos sociais e partidos políticos, bem como referendos.

Mortati oferece uma reflexão útil sobre a relevância desses conceitos liminares. Na sua opinião, a constituição material representa um ponto de entrada privilegiado para a análise conceitual. Ele deixa claro que a constituição material deve estar no cerne da análise constitucional porque a investigação do jurista sobre a base material do sistema legal não é apenas sociológica, mas uma análise genuinamente jurídica dos elementos do mundo social que o legislador tem que trazer à tona, e o sistema legal deve proteger para que uma comunidade seja “aquela comunidade”. De acordo com Mortati, o domínio epistêmico da constituição material possui fronteiras claras:

[o] jurista não faz sociologia, porque ele não busca os fatores que determinaram o surgimento de forças e ideologias em que o Estado se baseia; nem expressa qualquer opinião sobre eles. Ao traçar os recursos necessários para que as condutas e as relações sociais obtenham significado legal, ele delineia os fatos que emergem dessas mesmas relações à medida que se desdobram dentro de uma determinada ordem, que devem ser consideradas parte de sua constituição real ${ }^{90}$.

Esse reconhecimento da amplitude material dos estudos constitucionais tem consequências marcantes. Estudar o estado de exceção ou a doutrina de contralimites (bem como outras figuras prévias do direito constitucional, como o poder constituinte) através do prisma da constituição material enriquece estudos constitucionais por revelar a base material da relação entre direito, política e sociedade. O conceito de constituição material captura a relação interna entre a ordem constitucional e a sociedade sem eliminar a sua natureza conflituosa. É por meio dessa dinâmica que ocorre a mudança constitucional. Se a teoria constitucional serve para evitar o risco de se tornar irrelevante em suas abstrações, ela terá que lidar com isso. Mais ainda quando entramos num período em que o

\footnotetext{
${ }^{87}$ Vide especialmente a decisão de Lisboa da Corte Constitucional alemã, BVerfG, 2 BE 2/08, 30 June 2009.

${ }^{88}$ Essa doutrina diz que certos aspectos da identidade constitucionais não podem ser sacrificados em favor do direito supranacional [N. do T.].

89 Essa doutrina foi desenvolvida pelas cortes constitucionais da Alemanha e Itália: cf. V. Barsotti, P. Carozza, M. Cartabia, A. Simoncini, Italian Constitutional Justice in the Global Context (Oxford University Press 2016) $214-217$.

${ }^{90}$ C. Mortati, Una e indivisibile (Giuffré, 2007) § 18.
} 
constitucionalismo formal começa a parecer divorciado da realidade constitucional e a ordem constitucional está mais uma vez ameaçada por mudanças radicais.

\section{REFERENCIAS}

ANDERSON, B. Imagined Communities: Reflections on the Origin and Spread of Nationalism (Verso, 1983).

ARENDT, H. Origins of Totalitarianism (Harcourt, 1968).

ARISTOTLES. Politics [I.1.1252a1-7], [IV.1.1289a17-18].

BALIBAR, E. 'The Rise and Fall of the European Union: Temporalities and Teleologies' (2014) Constellations.

BALIBAR, E. Politics and the Other Scene (Verso, 2002).

BALKIN, J. Living Originalism (Harvard University Press, 2011).

BARSOTTI, V.; CAROZZA, P.; CARTABIA, M.; SIMONCINI, A. Italian Constitutional Justice in the Global Context (Oxford University Press 2016) 214-217.

BEARD, C. An Economic Interpretation of the Constitution of the United States (MacMillan, 1913).

BLOKKER, P. 'Politics and the Political in Sociological Constitutionalism' in P. Blokker and C. Thornhill (Ed.) Constitutional Sociology (Cambridge University Press, no prelo).

BLYTH, M. Austerity: The History of a Dangerous Idea (Oxford University Press, 2013).

BREAUD, O. 'Reframing a debate amongst Americans: Contextualizing a Moral Philosophy of Law' (2009) International Journal of Constitutional Law.

CASTORIADIS, C. The Imaginary Institution of Society, tr, K. Blamey (MIT Press, 1997).

CHRISTODOULIDIS, E. 'On the Politics of Societal Constitutionalism’ (2013) 20 Indiana Journal of Global Studies.

COVER, R. 'Nomos and Narrative’ (1983) 97 Harvard Law Review 4.

CROCE, M; SALVATORE, A. 'After Exception: Carl Schmitt's Legal Institutionalism and the Repudiation of Exceptionalism', in 29 Ratio Juris (2016).

CROCE, M; SALVATORE, A. The Legal Theory of Carl Schmitt (Routledge, 2012).

DELLA CANANEA, G. 'Mortati and the Science of Public Law' in C. Joerges, N. Ghaleigh (Ed.), Darker Legacies of Law in Europe (Hart Publishing, 2003). 
DYZENHAUS, D. 'Hermann Heller and the Legitimacy of Legality' (1996) 16 Oxford Journal of Legal Studies.

EWING, K. ‘The Resilience of the Political Constitution’ (2013) 14 German Law Journal 2111.

FISCHER, J. 'From confederacy to federation: thoughts on the finality of European integration' in C. Joerges, Y. Meny and J. H. H. Weiler (eds.) What Kind of Constitution for What Kind of Polity: Responses to Joschka Fischer (Jean Monnet Program Online Papers, 2001).

GAUCHET, M. The Disenchantment of the World: A Political History of Religion (Diane Publishing, 2001).

GINSBURG, T; SIMPSER, A. (Ed.) Constitutions in Authoritarian Regimes (Cambridge University Press, 2014).

GOLDONI, M; MCCORDINDALE, C. 'Political Constitutionalism', in M. Sellers (Ed.), Encyclopedia of the Philosophy of Law and Social Philosophy (Springer, 2017) (no prelo).

GRAMSCI, A. Selection from the Prison Notebooks (International Publishers, 1971).

GRIFFITHM, J. A. ‘The Political Constitution’ (1979) Modern Law Review.

GRIMM, D. 'Does Europe Need a Constitution?’ (1995) European Law Journal.

HABERMAS, J. Between Facts and Norms (MIT Press, 1992).

HARVEY, D. The New Imperialism (Oxford University Press, 2003).

HELLER, H. 'Political Democracy and Social Homogeneity' in A. Jacobson and B. Schlink (Ed.) Weimar: A Jurisprudence of Crisis (Berkeley, University of California Press, 2000).

HIRSCHL, R. Towards Juristocracy: The Origins and Consequences of the New Constitutionalism (Harvard University Press 2004).

KELSEN, H. Introduction to the Problems of Legal Theory, translated by B.L. Paulson \& S.L. Paulson (Oxford: Clarendon Press, 1992).

LA TORRE, M. 'The German Impact on Fascist Public Law: Costantino Mortati's Material Constitution' in C. Joerges, N. Ghaleigh (Ed.), Darker Legacies of Law in Europe (Hart Publishing, 2003).

LASSALLE, F. 'Uber Verfassungswesen' in 2 Gesammalte Reden Und Schriften 38 (E. Bernstein, ed.).

LINDAHL, H. 'Constituent Power and Reflexive Identity: Towards an Ontology of Collective Selfhood', in M. Loughlin, N. Walker (Ed.), The Paradox of Constitutionalism (Oxford University Press, 2007).

LOUGHLIN, M. 'Political Jurisprudence’ (2016) 16 Jus Politicum. 
LOUGHLIN, M. 'Ten Tenets of Sovereignty' in N. Walker (Ed.) Sovereignty in Transition (Hart, 2003).

LOUGHLIN, M. ‘The Constitutional Imagination’ (2015) 78 Modern Law Review.

LOUGHLIN, M. Foundations of Public Law (Oxford University Press, 2010).

LUXEMBURG, R. The Accumulation of Capital: A Contribution to an Economic Explanation of Imperialism (Routledge, 2003 [1913]).

MARX, K. The Eighteenth Brumaire of Louis Napoleon. Available at <www.marxists.org>.

MINKINNEN, P. 'Political Constitutionalism vs. Political Constitutional Theory: Law, Power and Politics’ (2015) 11 International Journal of Constitutional Law.

MÖLLERS, C. 'We are (afraid of) the people', in M. Loughlin and N. Walker (Ed.) The Paradox of Constitutionalism: Constitutional Power and Constitutional Form (Oxford University Press, 2007).

MORTATI, C. L’ordinamento del governo nel nuovo diritto pubblico italiano (Giuffré, 1931).

MORTATI, C. La costituzione in senso materiale (Giuffré, 1940).

MORTATI, C. Una e indivisibile (Giuffré, 2007) § 18.

MULLER, J-W. 'A General Theory of Constitutional Patriotism' (2008) International Journal of Constitutional Law.

NEGRI, A. Labor of Dionysus (University of Minnesota Press, 1994).

NEGRI, A; HARDT, M. Empire (Cambridge: Harvard University Press, 2000) xiv.

NEVES, M. Transconstitutionalism (Hart, 2013).

POLANYI, K. The Great Transformation: The Political and Economic Origins of Our Time (Beacon Press, 1944).

POOLE, T. Reason of State (Cambridge University Press, 2015).

POSNER, E; VERMEULE, A. The Executive Unbound (Oxford University Press, 2011).

POULANTZAS, N. State, Power, Socialism (Verso, 2014).

RANCIÈRE, J. Disagreement (University of Minnesota Press, 1999).

ROMANO, S. The Legal Order (Routledge, 2017).

SCHMITT, C. The Nomos of the Earth (Telos Press, 2006).

STRAUSS, D. The Living Constitution (Oxford University Press, 2010). 
STREECK, W. 'Taking Capitalism Seriously: Towards an Institutional Approach to Contemporary Political Economy’ (2011) Socio-Economic Review.

TEUBNER, G. Constitutional Fragments (Oxford University Press, 2012).

THORNHILL, C. A Sociology of Constitutions (Cambridge University Press, 2011).

WALUCHOW, W. A Common Law Theory of Judicial Review: The Living Tree (Cambridge University Press, 2007).

WILKINSON, M. 'Is Law Morally Risky? Alienation, Acceptance and Hart's Concept of Law' (2010) Oxford Journal of Legal Studies 441-466.

WILKINSON, M. 'The Euro is irreversible... Or is it?’ (2015) 16 German Law Journal.

WILKINSON, M. 'The Reconstitution of Postwar Europe: Lineages of Authoritarian Liberalism', LSE Law Society and Economy Working Paper Series, 05-2016.

WOLIN, S. 'The Liberal/Democratic Divide: on Rawl’s Political Liberalism’ (1996) 24 Political Theory.

WOOD, E. From Lords to Citizens: A Social History of Western Political Thought (Verso, 2011). 